\title{
IT required skills in accounting: A comparative analysis across European labour markets
}

\author{
Sînziana-Maria Rîndașu ${ }^{\mathrm{a}, 1}$ \\ ${ }^{a}$ Bucharest University of Economic Studies, Romania
}

\begin{abstract}
Research Question: The research proposition is to identify the information technology (IT) skills required from accounting professionals by the labour market from European emerging and developed economies and analyse whether there are differences between the requirements, depending on the type of economy.
\end{abstract}

Motivation: The wide adoption of several emerging technologies across various domains of activity is a widely debated topic. However, regardless of its popularity, little research focused on comparing the expectation of the professional bodies and the current labour market expectations in terms of the IT skills accountants should demonstrate.

Idea: This study aims to analyse if there is any gap between the expectations formulated by accounting professional bodies and the labour market's requirements in European countries regarding the IT skills accountants should demonstrate.

Data: The dataset selected for this study consisted of 1000 accounting job advertisements, collected between two periods: September 2017 - July 2018 and January - February 2021.

Tools: A cross-sectional study, including a content analysis and statistical analyses, was conducted to analyse the dataset collected.

Findings: The results illustrate the European labour market's current expectations regarding the IT skills accountants should demonstrate. The statistical analyses conducted highlight an association between the skills asked by emerging and developed European based companies.

Contributions: This paper provides a glimpse regarding the European labour market's expectations in terms of IT skills requested from accounting professionals, thus being a reference for the European professional bodies and academia.

Keywords: accounting education, information systems, IT skills, digitalised accounting, accounting graduates.

1 Corresponding author: Bucharest University of Economic Studies, Romania: 6 Piaţa Romană, $1^{\text {st }}$ District, Bucharest, 010374 Romania, sinziana_rindasu@yahoo.com 


\section{JEL codes: M15, M41, M54, O33}

\section{Introduction}

The accounting profession has been subject to tremendous changes in the last decades due to the considerable growth and development of information technologies (IT) solutions, such as Enterprise Resource Planning (ERP) systems, cloud computing, mobile technologies, and artificial intelligence (AI). This increasing interest in emerging technologies that might disrupt the accounting profession has heightened the need to research the companies' current demands regarding accountants' IT skills.

Nowadays, almost every process in the finance and accounting departments has been digitalised and the organisations' current needs modified. The changes in the professional accountants' role is not an element of novelty, being an aspect highlighted by researchers in the field (Albu et al., 2011), which requested national professional bodies to adopt a leadership position and facilitate the profession's efforts to adapt effectively to these changes. Hybrid jobs at the intersection of these two areas (accounting and information technology) have already been created (Guthrie et al., 2012). Expectations are that these new jobs will become representative for the profession's future.

Corporations are extensively investing in Robot Process Automation (RPA) solutions to increase productivity and reduce costs, leading to the automation of entry-level accounting processes (Bakarich \& O'Brien, 2020; Cooper et al., 2021) and the predictions are that almost all the processes will be, at some point, conducted solely with the use of robots. In this context, we might question the chances that fresh graduates can fill a position when most of their skills have already been automated. With just a few lines of code, a software can easily replace them, having greater precision and being more profitable. The overall trend is to adopt more efficient IT solutions to decrease costs and increase accuracy. Recent evidence highlighted that investing in IT solutions determines an increase in the organisations' profitability (Dow et al., 2017).

Worldwide, most accounting activities are outsourced and offshored, as this solution has been proved to be more profitable than the costs generated by an internal accounting department (Panigrahi \& Joshi, 2020). In emerging countries, the number of Business Process Outsourcing (BPO) and Shared Service Center (SSC) companies increased significantly because of the reduced expenditures. These companies do not perform the processes as initially transferred; they are optimising them. Along with these enhancements, procedures tend to simplify and the level of professional judgment required reduces at least in the case of the entry-level operations. 
According to a study conducted by PWC (2018), accounting practitioners expect that in the future, more than $30 \%$ of current jobs from Europe will disappear as a result of digitisation and $74 \%$ of them claim that they are ready to develop their set of skills to continue to add value to companies in the future. Shortly, employees' adaptability will become one of the most appreciated skills. Although there is a real risk that automating the activities will affect a significant part of practitioners, the human resources will not become expendable, as only their attributions will change. For this to be possible, the active involvement of professionals, academia, professional bodies, companies, and governments is necessary to facilitate this process.

During the last years, professional bodies (ACCA, 2017; ACCA 2018; ACCA, 2020a; ICAEW, 2018) have emphasised the need for future accountants to develop a new set of skills that combines accounting proficiency with more IT capabilities related to the current technologies used. Adopting new technologies is reshaping the profession as we know it today, as it allows the automation of specific processes. In this context, accountants should also improve their IT knowledge and skills to match the current demands. The shift of accountants from number crunchers to advisors cannot be avoided anymore as the professionals currently have at their disposal all the solutions needed to provide more value-added services, such as advising and providing strategic solutions. Moreover, with this avalanche of technologies (such as distributed ledgers, AI, and cloud computing) that brings more significant benefits, new threats appear, such as incorrect data manipulation and unintentional or deliberate exposure of confidential information. As per this, a new role of the future accountant emerges: caretaker of sensitive data.

However, although considerable research has been devoted to the IT-related skills that the accountants should master, in the light of adopting more efficient technical solutions, relatively less attention has been paid to the actual demands of the employers, to research whether the trends proposed by the professional bodies are aligned to the current market expectations.

This paper aims to investigate the IT skills required from accountants and the organisations' current expectations. In this regard, a cross-sectional study based on job requirements from emerging and developed European countries has been conducted to provide a glimpse of the skills accountants should possess.

This paper is structured in four parts. The first part presents the relevant literature review for this research, focusing on the IT skills accountants should demonstrate from the professional bodies and researchers' perspective. The second part details the methodology used to conduct the study, mentioning the purpose and objectives. The third part presents the results obtained and discussions regarding the job advertisements' analysis outcomes. The last part presents the conclusions, the limits of the present study, and future research directions. 


\section{Literature review}

This part of the study focuses on the expected skills professional accountants should demonstrate in the current context of digitalised accounting. The investigation is centred on cloud computing, business intelligence (BI), distributed ledgers, and AI as the most endorsed IT solution.

\subsection{Development of the accountants' skills - from number crunchers to advisors}

As the current economic environment creates a vast amount of data, new technologies are needed to store, process and manipulate the information efficiently. Process automation, cloud computing, and mobile accounting are just a few of these new technologies that have already become a core part of the accounting and finance functions.

Over the years, the international professional bodies issued a series of different reports focusing on the accountant's new role in the context of digitalisation. Evidences suggests that the accountant's traditional role will fade as a result of the automation of activities (ACCA, 2013; ACCA, 2020a; Frey \& Osborne, 2017; ICAEW, 2018) and technologies such as AI, distributed ledgers, and cloud platforms are critical differentiators for the future of the accountancy profession.

In the last decade, a series of changes have been observed in prestigious international professionals' requirements from Europe, such as ACCA, ICAEW, and CIMA. The aim was to highlight the changes from the accounting profession due to the growing volume of data, which became challenging to process and manage in the absence of optimal IT solutions.

In the accounting field, the first reports that addressed the need for development came from professional bodies and provided at least a partial picture of the profession's future in the context of digitisation. One of the most important articles was published in 2013 by ACCA. This report examined several technologies, some of them emerging at the time, considered to impact the accounting processes significantly. ACCA emphasised the need to understand how these technologies work and the main challenges that can lead to the loss or theft of confidential data once exposed in the digital environment.

To align the necessary skills of accounting professionals with the existing requirements of the companies, in 2014 the International Accounting Education Standards Board (IAESB) changes the structure of the International Educational Standard (IES 2) by introducing a new section for information technology. According to the modified version of the standard, practitioners must demonstrate 
an average level of competence in the IT field. Although the new standard was to take effect in 2015, in 2014, ACCA changed the structure of the P3 exam to align the curricula to the requirements. Thus, the chapter on information technology is amended by adding a new section that focuses on identifying, analysing, and evaluating controls regarding computer systems and technologies. The software skills part includes some of the essential controls for data security: access control, data integrity, and security.

CIMA (2015) also modifies the curricula by including the concepts of big data, digitalisation and emerging technologies as a response to both the requirements of the IAESB and the business environment. ICAEW had included a section on security in the curricula before the changes of IES2. However, starting with 2015, new requirements are introduced regarding system controls' assessment and technologies used in accounting.

The professional bodies (ACCA, 2020b; CIMA, 2019; ICAEW, 2021) continues to increase the level of awareness by introducing in their curricula special topics designed to help future professionals to create a sufficient base of knowledge and an adequate set of skills, such as:

- identifying the best hardware and software solutions;

- implementing and assessing controls using information systems;

- understanding and using emerging technologies, such as data analytics, cloud computing, AI, and distributed ledgers, along with data security and cyber risks.

Previous literature has clearly shown that with the usage of these technologies, the accountants now have a real opportunity to shift from number crunchers to advisors by taking advantage of the functions that these technologies provide (Appelbaum et al., 2017).

As prior literature emphasises, among most required core IT competencies organisations seek from accounting professionals are: AI, big data and data analytics, cloud computing, database analysis, distributed ledgers, and system design (Coyne et al., 2016; McKinney et al., 2017; Mangiuc, 2017; Moll \& Yigitbasioglu, 2019). Moreover, practitioners need to understand how technology might affect or enhance the quality of their activity (Islam, 2017; Mangiuc, 2017).

As we have previously presented, the international professional bodies support the accountants in understanding and efficiently using these technologies. However, without the implication of universities and local regulators of the accounting profession, most accountants will not gain, individually, the needed set of skills to face the challenges brought by these technologies. 


\subsection{Integrated IT subjects into the accounting curricula}

The integration of IT subjects into the accounting curricula is a highly debated topic in the literature. In the last decades, it was clear that the accounting processes will change due to technological development. However, at this point, sometimes the business environment is adopting new ways of performing the activities so that accounting skills might be at some point just desirable, but not required skills. Herbert et al. (2020) conclude, after analysing the current accounting processes and the transformation within the labour market from the UK, that a significant part of entry-level jobs has been automated and as an effect of the business process reengineering, graduates might become less employable and urges the accounting faculties to redesign the curricula, so it integrates subjects regarding AI and RPA.

A recent study (Kotb et al., 2019) highlighted the primary motivation in integrating into the accounting curricula IT subjects and although the majority of the professors interviewed acknowledged the importance of incorporating the technologies used by the labour market, only some of the respondents included in the modules IT-related aspects, the main limitations being the lack of staff and resources.

Since the objective of this study is to analyse the IT skills that the accounting practitioners should master, we cannot overlook the ability to work with Accounting Information Systems (AIS), as we expect to find in our study requirements regarding these skills, as it was the case of the study conducted by Albu et al. (2011). Nowadays, companies from different fields of activity started using ERP systems instead of AIS. The first one is a fully integrated and comprehensive end-to-end solution that incorporates all (or almost all) business activities. Previous research (Caglio, 2003; Albu et al., 2011) considers that the adoption of ERP systems in accounting facilitated the hybridisation between different accounting roles.

The AIS courses represent the first bridge between the accounting and IT fields in the accounting university training and profession. Nevertheless, prior research has shown that not all the accounting faculties merged with the Information System departments to facilitate the fusion between these two areas (Pan and Seow, 2016), which leads to the idea that graduates might not have at least a basic understanding of the IT solutions.

In the accounting literature, several studies accentuate the gap between the universities' curricula and the international bodies' expectations regarding IT skills. The curricula either do not contain sufficient AIS courses or there is a lack in the continuity of the IT competencies gained by the students during the study programs (Senik et al., 2013).

There is currently a gap between the accounting universities' curricula in Romania and international requirements (Stanciu \& Rîndașu, 2017) and the results showed that even in the case in which the accounting departments merge with the 
Information Systems departments, there are still inconsistencies between the academic curricula and professional bodies' requirements in the case of emerging technologies.

By analysing the changes in the curricula across accounting faculties, we discovered several studies focusing on integrating new IT topics. Stancheva-Todorova (2020) presents the strategy and challenges of a university from Bulgaria when introducing a new master program designed to complement the bachelor degree program by focusing on big data and BI. The main challenge faced by the university was to find the balance between the structure of the courses - if the courses focused only on fundamental aspects the professionals will lack practical skills.

The students' perception is another crucial factor in integrating IT subjects in the accounting curricula. A recent study from Romania (Stanciu et al., 2020) emphasised that future practitioners consider that BI, DBMS, and programming courses have a below-average importance for their careers. This outcome might be explained by the fact that most students start working in the accounting field after graduating from the bachelor degree program. For that matter, they might not have a complete understanding of the benefits brought by acquiring these skills.

Still, it seems that the universities are not preparing the students for a long-term career path, as the curricula are focusing more on entry-level requirements and theoretical aspects than on long-term career skills and practical experience (Lawson et al., 2013; Pratama, 2015; Herbert et al., 2020; Stanciu et al., 2020). Therefore, universities can sometimes be seen as an inhibitor of the profession (Watty et al., 2016) due to their late response in the face of the digital changes, despite professional bodies' recommendations. da Silva et al. (2020) highlighted that students are keen to embrace the new changes and wish to become active contributors in solving companies' IT issues. Still, they will need support from the universities in this process.

\section{Research methodology}

The professional bodies have already provided a glimpse of the accounting profession's future, concerning the merger between accounting and IT. The primary need is focused on the development of accounting professionals' IT skills, who should play a vital role in supporting organisations' value-added processes in the light of technological development.

This research aims to identify the IT skills requested by European-based companies from emerging and developed economies, having as a milestone the forecasts of international professional bodies. Thus, the general research objectives set out were:

O1. Analysing the current skills required or desired from accountants and evaluating whether there are gaps between the actual practice and the expectations formulated by professional bodies. 
O2. Identifying any significant differences between the requirements of companies from emerging and developed economies.

O3. Evaluating whether, between the two periods (2017-2018 and 2021), there were any significant changes regarding the required IT skills in the accounting field.

The research's general approach consists of conducting an exploratory crosssectional study to better capture different perspectives regarding employees' IT skills.

In this exploratory research, we analysed 1000 job offers from Bulgaria, Czech Republic, France, Germany, Hungary, Italy, Lithuania, Romania, Slovakia, and the United Kingdom available on different recruiting websites (annexe no. 1).

When starting this study, we had in mind prior research pointing out that emerging economies have been more conservative and rigid regarding changes in the accounting area (Martikainen \& Tilli, 2007). Moreover, in most emerging European countries (Bulgaria, Czech Republic, Hungary, Lithuania, and Romania), the accounting profession relies more on fiscal regulation and rigid accounting frameworks (Nobes \& Parker, 2008) rather than applying a principle-based approach. The other four countries in our selection are the most developed from Europe: France, Germany, Italy, and the United Kingdom.

The analysed sample has, in total, 1000 job advertisements, one hundred from each of the ten countries listed above. The first part of the sample was selected between September 2017 and July 2018 (50 jobs from each country), wishing to identify all the IT-related skills mentioned in the job advertisements either as desired or required. The rest of the sample was selected during January-February 2021. There were two reasons for extending this current research: firstly, to have a better representative sample. The second reason was based on a report issued in 2018 by the World Economic Forum (WEF). The report highlighted that by 2022, most of the jobs in accounting would disappear as a result of process automation and the new roles will focus on data analysis, big data, and data mining. Moreover, in the same report, it is suggested that most accountants will have to develop new skills. This report raised a red flag, as the practitioners should acquire the new competencies as soon as possible.

When selecting the job advertisements, we considered two conditions: the requirements mentioned either experience in the accounting field or a degree in accounting. We have chosen no more than two announcements from the same employing company for each country. The job requirements analysed from the countries mentioned above were solely in the accounting field. A centralisation of the data collected is presented in table 1 . 


\section{Results and discussions}

To achieve the study's first objective, we have performed a content analysis using the data collected from the job offers and examined the IT-related skills mentioned in the advertisements. After completing the investigation, we discovered that the ITrelated abilities referred to office software suite - OSS (word processors, spreadsheet editors, presentation programs, personal information management software, hosting services, and online communication tools), AIS, ERP, databases, database management systems (DBMS), optical character recognition (OCR), RPA, decentralised ledgers, and BI.

The most frequent required IT skill mentioned in 649 advertisements was proficiency in using the OSS, especially spreadsheet editors, representing $64.9 \%$ of the analysed data sample. Indeed, prior researches studying the skills needed from accountants presented the ability to work with OSS as essential (Bradbard et al., 2014; Uwizeyemungu et al., 2020). Nowadays, these skills of working with spreadsheets editors or word processors, search engines, personal information management software, and social networks are considered basic digital skills, mandatory for all professionals (European Commission, 2017). Although the professional bodies and researchers encourage the use of data analytics solutions instead of the classic spreadsheet editors, recent studies have highlighted that accountants are demonstrating resistance to move past Excel and rely on new solutions instead (Schmidt et al., 2020).

In terms of frequency, the next skill was represented by AIS and ERP systems. Since both of them are mainly used for the same purpose by the accounting professionals, we decided to allocate these skills in the same category and use the name AIS to denote AIS or ERP in the following part of the paper. From the total of 1000 jobs analysed in only 518 cases the companies mentioned that previous AIS experience was either a requirement or a desirable skill. The result is considered to be in line with the expected trends in a career for fresh graduates. However, for mid to senior levels, this condition should be mandatory, as nowadays, almost every accounting process is performed with the help of an AIS. Moreover, graduates should possess a certain proficiency level in using accounting software and economic universities must include this subject in their curricula. This will help them understand the digital accounting processes, the main controls, means of improvement, and how to respond to the reporting demands and security issues. This result is aligned with the previous research conducted by Uwizeyemungu et al. (2020); after analysing 171 job ads from Canadian companies, AIS was the second most required IT skill in terms of frequency.

In only 36 announcements, BI skills were required or desired; these positions were primarily related to reporting, controlling, and analysis. In some cases, the 
advertisements also mentioned the solutions, such as Oracle Business Intelligence, SAP BW, and Power BI. Since most of the offers did not specify the software used, we could not identify whether the future employee will have to demonstrate skills regarding data mining as some of the IT solutions listed above provide this feature. In other cases, the job offers were mentioning only "detailed expertise using business intelligence applications" or "experience with BI tools". Still, having in mind the benefits of using BI (Amani \& Fadlalla, 2017, Sledgianowski et al., 2017), this outcome is somehow unsatisfactory as it enhances the idea that the organisations from the countries analysed might not be seeing the full potential of these technologies. Comparing the two examined periods, 2017-2018 versus 2021, it can be seen that the number of jobs in which BI skills were either required or desired increased significantly and the expectations are for this trend to persist in the future.

Required or desired skills regarding databases and DMBS (RD\&DBMS) were identified in 23 job offers. A study focusing on Romania's accounting education (Stanciu \& Rîndașu, 2017) identified that the majority of study programs have in their curricula courses regarding RD\&DBMS. In this context, this result highlights that the employees might not be completely aware of the skills that practitioners have developed during the academic education programs. To think that this skill is somehow redundant for accountants, we must keep in mind that in the current digitalised accounting, AIS are used extensively and practitioners should understand the relational model used by the systems, if not also regarding the implementation. These skills are meant to enhance the performance of individuals, especially when working with large data sets. Although RD\&DBMS courses are included in the curricula, the agenda is not focused on accounting processes but rather on a syllabus that does not keep students engaged. By concentrating more on the practical side of using RD\&DBMS and providing clear and practical examples, future practitioners will have a better understanding of data analysis. For example, a recent study (Lawson and Street, 2021) has demonstrated how accountants can leverage the skills acquired from RD\&DBMS courses to discover rogue data.

Four job offers mentioned VBA skills as desirable, VBA being an event-driven programming language mainly used to automate tasks. In only one case we have identified for an accounting position the requirement that the candidate should have working experience with RPA and OCR solutions, which are part of the AI domain. In another job ad it was specified that the future employee should manage projects focusing on digitalisation and automation techniques. However, we did not find sufficient information to clearly state that the recruitment advertisement referred to automation using AI or other non-AI solutions, such as VBA.

Skills regarding distributed ledgers (DL) were specified only in one job advertisement where this was not mandatory, but a desirable skill: "in a perfect world you will have understanding of crypto-accounting or have experience working with several currencies and/or intangible assets.". None of the jobs offers mentioned cloud 
computing skills. This result can be partially explained by the fact that these solutions are still emerging and there is no significant level of adoption. However, given the probable rise of these technologies in the near future, we expect to notice these skills more often in the next couple of years. A recent study conducted by Ferri et al. (2020) which aimed to investigate the drivers of using the blockchain technology in the accounting and audit processes, unveiled that the primary motivators are the social influence and the expected performance of the technology. Thus, without exposure to the distributed ledgers during the academic training or the continuous development program, the accountants cannot form an objective opinion.

Since international professional associations consider that accounting practitioners should have a good understanding of IT systems to the point in which they can advise what solution is suitable for the business needs, at least in terms of the accounting and reporting activities, we have also analysed whether the job advertisements mentioned any collaboration between the future employees and IT departments and we have identified five cases. These were not required or desired skills and were presented on the attributions list (three from France, one from Germany and the last one from the United Kingdom). The statements were the following: "participate in defining the IT strategy", "make any proposal regarding IT software requirements and improvements to existing software so that the IT tool is continually adapted to the needs of accounting and financial services", "contribute to Sage and ERP improvement by working with IT and other departments", "assist in the implementation of our ERP system", and "liaise with IT system developers to understand data and promote system developments".

As these emerging technologies used in the accounting profession increase the risk of sensitive data leakage, we have also analysed if any of the job advertisements included such requirements, as proficiency in implementing and assessing controls and any data security-related skills. However, no job that fulfils these conditions was encountered. This result raises concerns as not all companies are training their employees regarding information security threats. Given the level of personal data used in accounting and the General Data Protection Regulation that came into effect in 2018, organisations are at risk of being fined if the employees are not complying with the regulation when using personal data.

Table 1: Centralization of the results

\begin{tabular}{|c|c|c|c|c|c|c|c|}
\hline Country & AI & AIS & BI & $\begin{array}{l}\text { RD\&DBMS } \\
2017-2018 / 2021\end{array}$ & $\overline{\text { DL }}$ & OSS & VBA \\
\hline Bulgaria & - & $22 / 25$ & $1 / 2$ & $1 / 1$ & - & $45 / 39$ & - \\
\hline Czech Republic & - & $24 / 28$ & $0 / 2$ & $0 / 1$ & - & $39 / 33$ & - \\
\hline France & - & $24 / 22$ & $0 / 4$ & $0 / 1$ & - & $25 / 23$ & - \\
\hline Germany & - & $36 / 41$ & $2 / 6$ & $2 / 0$ & - & $35 / 37$ & - \\
\hline Hungary & $0 / 1$ & $20 / 27$ & $0 / 2$ & $1 / 1$ & - & $36 / 32$ & - \\
\hline Italy & - & $26 / 26$ & $1 / 2$ & $2 / 1$ & - & $27 / 33$ & - \\
\hline
\end{tabular}


IT required skills in accounting: A comparative analysis across European labour markets

\begin{tabular}{lccccccc}
\hline \multicolumn{1}{c}{ Country } & AI & AIS & BI & $\begin{array}{c}\text { RD\&DBMS } \\
\mathbf{2 0 1 7 - 2 0 1 8 / 2 0 2 1}\end{array}$ & DL & OSS & VBA \\
\hline Lithuania & - & $22 / 22$ & $0 / 5$ & $1 / 2$ & - & $26 / 26$ & - \\
Romania & - & $30 / 25$ & $0 / 3$ & $1 / 2$ & - & $36 / 35$ & - \\
Slovakia & - & $22 / 24$ & $0 / 1$ & $0 / 2$ & - & $31 / 37$ & $0 / 3$ \\
UK & - & $26 / 26$ & $1 / 4$ & $2 / 2$ & $0 / 1$ & $26 / 28$ & $0 / 1$ \\
Total & $\mathbf{0 / 1}$ & $\mathbf{2 5 3 / 2 6 5}$ & $\mathbf{5 / 3 1}$ & $\mathbf{1 0} / \mathbf{2 3}$ & $\mathbf{0} / \mathbf{1}$ & $\mathbf{3 2 6} / \mathbf{3 2 3}$ & $\mathbf{0} / \mathbf{4}$ \\
\hline \multicolumn{7}{c}{ Source: own processing based on the data collected } \\
\end{tabular}

Although the number of jobs in which RB\&DBMS and BI skills were either required or desired increased in 2021 compared with the previous analysed period, the number of advertisements is still relatively small to conduct a statistical analysis.

As in the case of the study conducted by Uwizeyemungu et al. (2020), we have not discovered any IT-related competency that is not covered by the courses provided by the majority of accounting faculties in Europe or promoted by professional bodies. Nevertheless, comparing the findings of this study with the results obtained by Uwizeyemungu et al. (2020), in the current sample, we did not encounter any job advertisements that will require competencies regarding IT governance, protection technologies and software, or computer and telecommunication networks.

In the selected sample, we have found 209 items, representing $20.9 \%$ of the total dataset, having no mentions of any particular IT skills the candidate should demonstrate. In some cases, we have found some abstract requirements. Several examples are the following: "commits to being knowledgeable and up-to-date with relevant technologies", "have a high affinity for IT topics", "proficiency with IT tools is essential", and "a good command of IT tools and architectures". Since the ads did not specify the skills required or desired by the employers, we could not deduct what skills are needed, as various IT tools are used in the accounting domain.

After assessing the research results, the authors concluded that this outcome indicates that organisations might undervalue the accounting professionals through the presented job requirements. Their job advertisements focused primarily on essential digital competencies and AIS. One logical explanation for this aspect is that, as previously stated by Albu et al. (2012), about the accounting profession from Romania, there is a gap between the current role of accountants and their true potential as advisors and strategists. We, therefore, might conclude that the accountants' capabilities might be disregarded in these countries analysed. The minimal IT skills and knowledge emphasised by the accounting international professional bodies, part of their requirements for accountants' certification, should be a valuable benchmark for the companies worldwide and not a key differentiator for remuneration.

Regarding the second objective of this research, assessing if there are any significant statistical differences between emerging and developed economies in terms of the 
skills asked from accountants, we performed a chi-square test for independence, using the Statistical Package for Social Sciences (SPSS).

Given that in the case of BI, AI, DB\&DBMS, and VBA, there were only a few job advertisements identified, we performed the tests only for AI and OSS. Both tests had two categorical variables with two groups. The first test's variables were the country (emerging versus developed) and AIS skills (AIS versus non-AIS), having, for the second test, the country and office software suite (OSS versus non-OSS) as variables.

The chi-square test hypotheses formulated for the first analysis were the following:

$H 0_{1}$ : There is no association between the type of country (emerging or developed) and the AIS skills required or desired.

$\mathrm{Ha}_{1}$ : There is an association between the type of country (emerging or developed) and the AIS skills required or desired.

For the second chi-square test analysis the hypotheses formulated were the following:

$\mathrm{HO}_{2}$ : There is no association between the type of country (emerging or developed) and the OSS skills required or desired.

$\mathrm{Ha}_{2}$ : There is an association between the type of country (emerging or developed) and the OSS skills required or desired.

After analysing the results obtained after performing both chi-square tests, having the p-value of 0.011 in the case of AIS skills (table 2) and 0.001 in the case of OSS skills (table 3 ), we rejected the null hypotheses $\left(\mathrm{HO}_{1}\right.$ and $\left.\mathrm{HO}_{2}\right)$ with a level of confidence of $95 \%$ and concluded that there is an association between the types of country and the expected skills. However, as observed from the Phi-value in both cases (table 4 and table 5), the association's effect is small between the variables.

Table 2. Chi-Square Tests for AIS

\begin{tabular}{lccccc}
\hline & Value & Df & $\begin{array}{c}\text { Asymp. } \\
\text { Sig. } \\
\text { (2-sided) }\end{array}$ & $\begin{array}{c}\text { Exact Sig. } \\
\text { (2-sided) }\end{array}$ & $\begin{array}{c}\text { Exact Sig. } \\
\text { (1-sided) }\end{array}$ \\
\hline Pearson Chi-Square & $6.542^{\mathrm{a}}$ & 1 & .011 & & \\
Continuity Correction $^{\mathrm{b}}$ & 6.216 & 1 & .013 & & \\
Likelihood Ratio & 6.556 & 1 & .010 & & \\
$\begin{array}{l}\text { Fisher's Exact Test } \\
\text { N of Valid Cases }\end{array}$ & 1000 & & & .012 & .006 \\
\hline
\end{tabular}

a. 0 cells $(.0 \%)$ have expected count less than 5 . The minimum expected count is 192.80 .

b. Computed only for a $2 \times 2$ table 
Table 3. Chi-Square for OSS

\begin{tabular}{lccccc} 
& Value & Df & $\begin{array}{c}\text { Asymp. Sig. } \\
\text { (2-sided) }\end{array}$ & $\begin{array}{c}\text { Exact Sig. } \\
\text { (2-sided) }\end{array}$ & $\begin{array}{c}\text { Exact Sig. } \\
\text { (1-sided) }\end{array}$ \\
\hline Pearson Chi-Square & $11.987^{\mathrm{a}}$ & 1 & .001 & & \\
Continuity Correction ${ }^{\mathrm{b}}$ & 11.523 & 1 & .001 & & .000 \\
Likelihood Ratio & 11.913 & 1 & .001 & & \\
Fisher's Exact Test & & & & & \\
N of Valid Cases & 1000 & & & \\
\hline a. 0 cells (.0\%) have expected count less than 5. The minimum expected count is 140.40 \\
\\
b. Computed only for a 2x2 table
\end{tabular}

Table 4. Symmetric Measures for AIS

\begin{tabular}{llcc}
\hline & & Value & Approx. Sig. \\
\hline Nominal by & Phi & .081 & .011 \\
Nominal & Cramer's V & .081 & .011 \\
N of Valid Cases & & 1000 & \\
\hline
\end{tabular}

Table 5. Symmetric Measures OSS

\begin{tabular}{lccc}
\hline & & Value & Approx. Sig. \\
\hline Nominal by & Phi & -.109 & .001 \\
Nominal & Cramer's V & .109 & .001 \\
N of Valid Cases & & 1000 & \\
\hline
\end{tabular}

By performing these analyses, we achieved the second objective of the research and we can conclude that there are statistically significant differences between emerging and developed economies in terms of the skills asked from accountants, but the effect size is weak.

To achieve the third objective of the research, we have performed other chi-square analyses to test whether the job requirements in accounting have changed due to the extending digitalisation of processes. As in the case of the second objective, since the only statistically significant volume of skills was identified in the case of OSS and AIS, we conducted two chi-square tests. The third test's categorical variables were panel (Panel A - for the dataset collected during 2017-2018 versus Panel B for the dataset collected in 2021) and AIS skills required (AIS versus non-AIS) and for the fourth test panel (Panel A versus Panel B) and OSS (OSS versus non-OSS).

The third chi-square test performed had the following hypotheses:

$H_{3}$ : There is no association between the panel and the AIS skills required or desired. 
$\mathrm{Ha}_{3}$ : There is an association between the panel and the AIS skills required or desired.

For the fourth chi-square test analysis the hypotheses formulated were the following:

$\mathrm{HO}_{4}$ : There is no association between the panel and the OSS skills required or desired.

$H a_{4}$ : There is an association between the panel and the OSS skills required or desired.

The p-values of 0.486 in the case of the AIS skills (table 6) and 0.842 in OSS skills (table 7) determined us to accept the null hypotheses and conclude that there is no association between the panels and the skills. These results emphasise that during the period 2017-2021, there were no significant changes between accounting professionals' IT skills regarding AIS systems or OSS skills. We expected that there would be a significant statistical association as predicted by the WEF report mainly because, in the last years, companies started to increase the number of remote jobs and, in the absence of face-to-face training, employees should demonstrate sufficient skills to perform the job requirements. However, the chi-square tests did not confirm our expectations.

Table 6. Chi-Square Tests for AIS

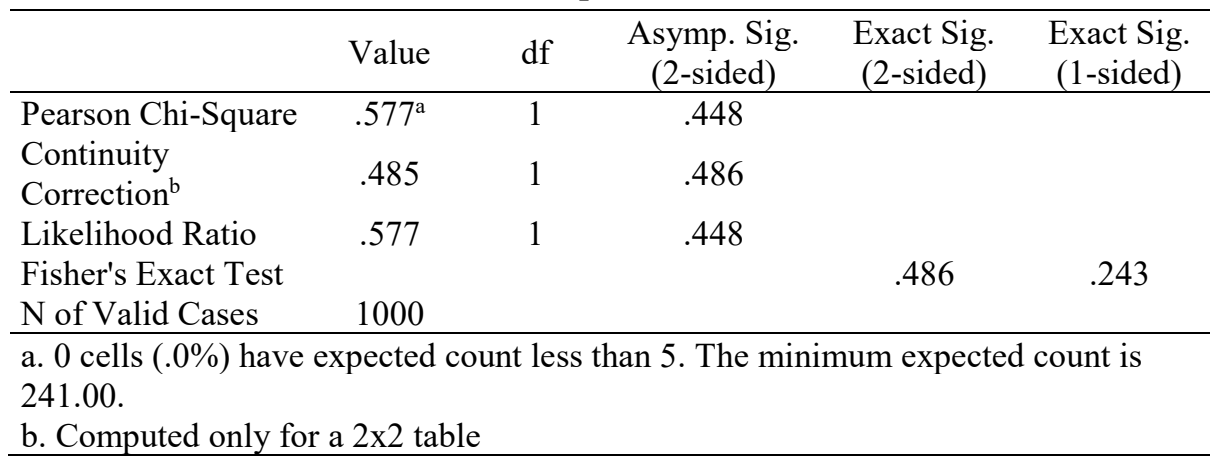

Table 7. Chi-Square Tests for OSS

\begin{tabular}{lccccc}
\hline & Value & df & $\begin{array}{c}\text { Asymp. Sig. } \\
(2 \text {-sided })\end{array}$ & $\begin{array}{c}\text { Exact Sig. } \\
(2 \text {-sided })\end{array}$ & $\begin{array}{c}\text { Exact Sig. } \\
\text { (1-sided) }\end{array}$ \\
\hline Pearson Chi-Square & $.040^{\mathrm{a}}$ & 1 & .842 & & \\
Continuity & .018 & 1 & .895 & & \\
Likelihood Ratio & .040 & 1 & .842 & & .447 \\
Fisher's Exact Test & & & & .895 &. \\
N of Valid Cases & 1000 & & & & \\
\hline
\end{tabular}

a. 0 cells $(.0 \%)$ have expected count less than 5 . The minimum expected count is 175.50 .

b. Computed only for a $2 \times 2$ table 
The outcomes of the study can be explained through four perspectives:

- Some companies do not consider it mandatory for candidates to have a particular set of IT skills as these capabilities will be gained by the professional after taking some internal training. However, this approach is costly and the company is not fully benefiting from the employees' IT skills.

- Future employees will not need any other IT skills besides AIS and OSS to perform their roles, as the presented technologies are not being used or the company is focusing only on the present or short-term needs.

- The recruiters might not have complete visibility and understanding of the context in which the professionals will work and the job descriptions might not fully cover the required area of expertise.

- From an accounting education point of view, although many accounting faculties incorporated some of the technologies promoted by the professional bodies in their curricula, the labour market is not satisfied with the skills graduates are acquiring. This fact might result from the fact that the IT educators do not have sufficient knowledge regarding using the technologies they are teaching from an accounting perspective, as a prior study suggests (Kotb et al., 2019).

In the future, one of the critical challenges for companies will be to employ well enough trained practitioners to perform activities that cannot be facilitated by technological progress. As per this, the business model and companies' objectives will have to be redesigned so that employees are appreciated for their contribution. Worldwide, employees currently prefer to change jobs much more frequently than in the past, the primary motivation being more attractive salary packages and professional development opportunities. In the context in which not all practitioners will develop the necessary skills, companies will need to find solutions to increase the retention rate to continue to remain competitive.

\section{Conclusions}

This research revealed clear evidence that the accounting profession is changing due to the current extensive adoption of IT solutions. These new technologies aiming to facilitate the overall processes in this field and international professional bodies are trying to increase the level of awareness regarding the need to efficiently use new IT technologies and dedicated software tools, as well as protecting the sensitive information from possible vulnerabilities brought by the digital revolution in accounting.

After performing a content analysis targeting one thousand job advertisements from ten European emerging and developed countries, we discovered that accountants' IT skills level demanded is relatively low. When we decided to conduct this study on 
emerging economies, we expected a certain level of conservatism. However, giving the fact that the majority of the digital skills required focused more on basic capabilities (OSS skills), while just half of the analysed items mentioned mandatory or desired AIS skills, we concluded that either organisations are not fully harnessing the actual IT potential of their current and future employees or the professionals' IT skills are not sufficiently developed to formulate such demands. Although, as presented in the literature review, sometimes accounting educators might respond late to the labour market requirements, still to do so, they should receive all the necessary information regarding the demands from the labour markets.

The overall result of this study highlights the fact that in Europe, the labour market does not expect accounting practitioners to demonstrate skills regarding IT solutions, except for AIS and OSS. However, some faculties have included in their curricula courses relating to AI, distributed ledgers, and Big Data, yet most employers do not require these skills. Therefore, accounting faculties should analyse what they can improve so that the future practitioners' skills will be appreciated and sought by the labour market.

A limitation of this study is that there are many small companies in Europe and they might not have yet adopted some of the technologies presented in this paper. The company size analysis has not been performed in this study as some job advertisements were from recruitment companies that did not specify the customer's name, the companies' employee number, or size. The same logic applies in the case of the field of activity, although this should not have a significant influence.

The authors expect that this outcome will suffer some changes in the near future, as more and more technologies that reduce the redundant processes will be adopted to cope with the economic realities. Digital environment extension and complexity will impose new and solid IT skills from professional accountants. In this respect, employment demands will be updated accordingly. The permanent dialogue and cooperation between accounting faculties, professional bodies, and employers will ensure the curricula's adjustment so that the future practitioners' training will respond to the professional requirements in a highly digitalised environment.

\section{Acknowledgments}

We appreciate the helpful and constructive recommendations received on this study during the International Conference Accounting and Management Information Systems (AMIS 2021), Bucharest, Romania. Special thanks are addressed to the anonymous reviewers of this conference. 


\section{References}

Albu, C.N., Albu, N., Faff, R. \& Hodgson, A. (2011) “Accounting competencies and the changing role of accountants in emerging economies: the case of Romania”, Accounting in Europe, vol. 8, no. 2: 155-184

Albu, N., Albu, C. \& Gîrbină, M. (2012) "Educating accounting students in an emerging economy-an analysis of the importantance of stereotypes in teaching IFRS", International Journal of Academic Research, vol. 4, no. 3: $51-57$

Amani, F. A. \& Fadlalla, A.M. (2017) "Data mining applications in accounting: A review of the literature and organizing framework", International Journal of Accounting Information Systems, vol. 24: 32-58

Appelbaum, D., Kogan, A. Vasarhelyi, M. \& Yan, Z. (2017) "Impact of business analytics and enterprise systems on managerial accounting", International Journal of Accounting Information Systems, vol. 25: 29-44

Association of Chartered Certified Accountants - ACCA (2013) "Technology trends: their impact on the global accountancy profession", available on-line at http://www.accaglobal.com/zw/en/technical-activities/technical-resourcessearch/2013/may/technology-trends.html retrieved March 25, 2018

Association of Chartered Certified Accountants - ACCA (2014) "Changes to the ACCA Qualification Skills module and Professional level in 2014-15", available on-line at https://www.accaglobal.com/us/en/student/examsupport-resources/fundamentals-examsstudy-resources/f4/technicalarticles/qualification-changes.html retrieved March 25, 2018

Association of Chartered Certified Accountants - ACCA (2017) "Divided We Fall, Distributed We Stand: The Professional Accountant's Guide to Distributed Ledgers and Blockchain", available on-line at https://www.accaglobal.com/content/dam/ACCA_Global/Technical/Future /Divided\%20we\%20

fall $\% 2 \mathrm{C} \% 20$ distributed $\% 20 \mathrm{we} \% 20$ stand $\% 20 \% 20$ The $\% 20$ professional $\% 20$ accountant $\%$ E2\%80\%99s\%20guide $\% 20$ to $\% 20$ distributed $\% 201$ edgers $\% 20$ a nd\%20blockchain.pdf retrieved November 5, 2020

Association of Chartered Certified Accountants - ACCA (2018) "An RPA Guide for Finance Functions", available on-line at https://www.accaglobal.com /content/dam/ACCA_Global/Technical/Reports/ACCA-KPMG\% 20Robotics\%20Report_FINAL_web.pdf retrieved November 5, 2020

Association of Chartered Certified Accountants- ACCA (2020a) "Future ready: accountancy careers in the 2020s", available on-line at https://www.accaglobal.com/content/dam/ACCA_Global/professionalinsights/FutureReady2020s/JamieLyon.FutureCareersAccoutancy2020s.ful lreport.pdf retrieved March 16, 2021

Association of Chartered Certified Accountants - ACCA (2020b) "Business and Technology (BT/FBT) Syllabus and study guide", available on-line at 
https://www.accaglobal.com/in/en/student/exam-support-

resources/fundamentals-exams-study-resources/f1/syllabus-studyguide.html\# retrieved September 16, 2020

Bakarich, K.M. \& O'Brien, P. (2020) "The robots are coming... but aren't here yet: The use of artificial intelligence technologies in the public accounting profession", Journal of Emerging Technologies in Accounting, in press

Bradbard, D. A., Alvis, C. \& Morris, R. (2014) "Spreadsheet usage by management accountants: An exploratory study", Journal of Accounting Education, vol. 32 , no. 4: $24-30$

Caglio, A. (2003) "Enterprise Resource Planning systems and accountants: towards hybridization?", European Accounting Review, vol. 12, no. 1: 123-153

Chartered Institute of Management Accountants - CIMA (2015) "2015 CIMA professional qualification syllabus", available on-line at https://www.cimaglobal.com/Documents/Student\%20docs/2015-

syllabus/CIMA-2015-professional-qualificationsyllabus.pdf retrieved November 18, 2018

Chartered Institute of Management Accountants - CIMA (2019) "2019 CIMA professional qualification syllabus", available online at https:/www.cimaglobal.com/Documents/Future\%20of\%20Finance/1807$5335 \% 20$ Future $\% 20$ of $\% 20$ Finance $\% 20-\% 20$ Syllabus_WEB_R2_ IT\%20\%2005 \%20Feb.pdf retrieved December 12, 2020

Cooper, L.A., Holderness, D.K., Sorensen, T.L. \& Wood, D.A. (2021) "Perceptions of Robotic Process Automation in Big 4 public accounting firms: Do firm leaders and lower-level employees agree?", Journal of Emerging Technologies in Accounting, in press

Coyne, J. G., Coyne, E. M. \& Walker, K.B. (2016) "A model to update accounting curricula for emerging technologies", Journal of Emerging Technologies in Accounting, vol. 13, no. 1: 161-169

da Silva, R.J., Tommasetti, R., Gomes, M.Z. \& da Silva Macedo, M.A. (2020) "Accountants' IT responsibilities and competencies from a student perspective", Higher Education, Skills and Work-Based Learning, in press

Dow, K. E., Watson, M.W. \& Shea, V. J. (2017) "Riding the waves of technology through the decades: The relation between industry-level information technology intensity and the cost of equity capital", International Journal of Accounting Information Systems, vol. 25: 18-28

European Commission (2017) "ICT for work: Digital skills in the workplace", available on-line at https://ec.europa.eu/digital-single-market/en/news/ictwork-digital-skills-workplace retrieved November 24, 2017

Ferri, L., Spanò, R., Ginesti, G. \& Theodosopoulos, G. (2020) "Ascertaining auditors' intentions to use blockchain technology: evidence from the Big 4 accountancy firms in Italy", Meditari Accountancy Research, in press 
Frey, C.B. \& Osborne, M.A. (2017) “The future of employment: how susceptible are jobs to computerisation?", Technological Forecasting and Social Change, vol. 114: 254-280

Guthrie, J., Burritt, R. \& Evans, E. (2012) "Challenges for accounting pathways in Australia in 2012: an introduction. Emerging pathways for the next generation of accountants", available on-line at https://www.unisa.edu.au/Global/business/centres/cags/docs/Emerging\%20 pathways $\% 20$ for $\% 20$ the $\% 20$ next $\% 20$ generation $\% 20$ of $\% 20$ accountants.pd f retrieved March 10, 2018

Herbert, I.P., Rothwell, A.T., Glover, J.L. \& Lambert, S.A. (2020) "Does the changing world of professional work need a new approach to accounting education?", Accounting Education, vol. 30, no. 2: 188-212

Institute of Chartered Accountants in England and Wales - ICAEW (2013) "Latest evolution of the ACA Syllabus 2014 - certificate and professional levels", available on-line at: https:/www.icaew.com/-/media/corporate/files/ learning-and-development/learningpartners/hei/cpl/syllabus-latest-evolutio n-of-the-aca-certificate-andprofessional-levels-2014.ashx retrieved November 20, 2018

Institute of Chartered Accountants in England and Wales - ICAEW (2014) "ACA Syllabus and technical knowledge grids for exams in 2015", available online at https://www.icaew.com/-/media/corporate/files/learning-anddevelopment/learningpartners/hei/cpl/aca-syllabus-and-technicalknowledge-grids-2015.ashx retrieved November 20, 2018

Institute of Chartered Accountants in England and Wales - ICAEW (2018) "Artificial intelligence and the future of accountancy", available on-line at https://www.icaew.com/-

/media/corporate/files/technical/technology/thought-leadership/artificialintelligence-report.ashx retrieved March 6, 2021

Institute of Chartered Accountants in England and Wales - ICAEW (2021) "ACA syllabus and technical knowledge grids", available on-line at https://www.icaew.com/-/media/corporate/files/learning-anddevelopment/aca-syllabus/2021-aca-syllabus-handbook_professional.ashx retrieved September 16, 2020

International Accounting Education Standards Board (2014) "IES 2, Initial Professional Development-Technical Competence", available on-line at https://www.ifac.org/publications-resources/ies-2-initial-professionaldevelopmenttechnical-competence-revised/ retrieved November 20, 2018

Islam, M. A. (2017) "Future of Accounting Profession: Three Major Changes and Implications for Teaching and Research", Business Reporting, International Federation of Accountants (IFAC), available on-line at http://www.ifac.org/global-knowledge-gateway/businessreporting/discussion/future-accounting-profession-three-major retrieved November 10, 2017 
Kotb, A., Abdel-Kader, M., Allam, A., Halabi, H. \& Franklin, E. (2019) "Information technology in the British and Irish undergraduate accounting degrees", Accounting Education, vol. 28, no. 5: 445-464.

Lawson, J.G. \& Street, D.A. (2021) "Detecting dirty data using SQL: Rigorous house insurance case", Journal of Accounting Education, vol. 55.

Lawson, R. A., Blocher, E. J., Brewer, P. C., Cokins, G., Sorensen, J. E., Stout, D. E. \& Wouters, M. J. (2013) "Focusing accounting curricula on students' long-run careers: Recommendations for an integrated competency-based framework for accounting education", Issues in Accounting Education, vol. 29 , no. 2 : 295-317

Mangiuc, D. (2017) "Accountants and the cloud-Involving the professionals", Journal of Accounting and Management Information Systems, vol. 16, no. 1: 179-198

Martikainen, M. \& Tilli. S. (2007) "Reliability of earnings figures and conservatism in transitional economies", available on-line at https://papers.ssrn.com /sol3/papers.cfm?abstract_id=992747 retrieved November 15, 2017

McKinney, E. C., Yoos, J. \& Ken, S. (2017) "The need for 'skeptical' accountants in the era of Big Data", Journal of Accounting Education, vol. 38: 63-80

Moll, J. \& Yigitbasioglu, O. (2019) "The role of internet-related technologies in shaping the work of accountants: New directions for accounting research", The British Accounting Review, vol. 51, no. 6: 1-20

Nobes, C. \& Parker, R. H. (2008) Comparative international accounting, London: Pearson Education

Pan, G. \& Seow, P.S. (2016) "Preparing accounting graduates for digital revolution: A critical review of information technology competencies and skills development", Journal of Education for Business, vol. 91, no. 3: 166-175

Panigrahi, C.M.A. \& Joshi, V. (2020) "Outsourcing-The Modern Trend of Accounts Management", Wutan Huatan Jisuan Jishu, vol. 16: 268-283

Pratama, A. (2015) "Bridging the Gap between Academicians and Practitioners on Accountant Competencies: An Analysis of International Education Standards (IES) Implementation on Indonesia's Accounting Education", Procedia-Social and Behavioral Sciences, vol. 211: 19-26

PWC (2018), "Workforce of the future - The competing forces shaping 2030", available on-line at https://www.pwc.com/gx/en/services/peopleorganisation/workforce-of-the-future/workforce-of-the-future-thecompeting-forces-shaping-2030-pwc.pdf retrieved July 20, 2021

Schmidt, P.J., Church, K.S. \& Riley, J. (2020) "Clinging to Excel as a security blanket: Investigating accountants' resistance to emerging data analytics technology", Journal of Emerging Technologies in Accounting, vol. 17, no. 1: 33-39.

Senik, R., Broad, M., Mat, N. \& Kadir, S. A. (2013) "Information technology (IT) knowledge and skills of accounting graduates: Does an expectation gap exist?", Jurnal Pengurusan (UKM Journal of Management), vol. 38: 89-100 
Sledgianowski, D., Gomaa, M., \& Tan, C. (2017) "Toward integration of Big Data, technology and information systems competencies into the accounting curriculum", Journal of Accounting Education, vol. 38: 81-93

Stancheva-Todorova, E. P. (2019) "Integrating Big data analytics competence into the accounting curriculum", Съвременни управленски практики, vol. X: $170-177$

Stanciu V. \& Rîndașu, S. (2017) "Emerging information technologies in accounting - are the aspiring professional accountants prepared to face the challenges? A case study of Romanian universities", Proceedings of the 29th International Business Information Management Association Conference: 2455-2467

Stanciu, V., Pugna, I.B. \& Gheorghe, M. (2020) "New coordinates of accounting academic education. A Romanian insight", Accounting and Management Information Systems, vol. 19, no. 5: 158-178

Uwizeyemungu, S., Bertrand, J. \& Poba-Nzaou, P. (2020) "Patterns underlying required competencies for CPA professionals: a content and cluster analysis of job ads", Accounting Education, vol. 29, no. 2: 109-136

Watty, K., McKay, J. \& Ngo, L. (2016) "Innovators or inhibitors? Accounting faculty resistance to new educational technologies in higher education", Journal of Accounting Education, vol. 36: 1-15

World Economic Forum (2018), "The Future of Jobs Report 2018", available online at http://www3.weforum.org/docs/WEF_Future_of_Jobs_2018.pdf retrieved March 3, 2019

\section{ANEXES}

\section{Annex no. 1: List of the recruiting sites used to collect the job} advertisements

1. https://de.indeed.com/

2. https://it.indeed.com

3. https://offre-demploi.monster.fr

4. https://www.cadremploi.fr

5. https://www.cvonline.lt/

6. https://www.ejobs.ro/

7. https://www.indeed.co.uk

8. https://www.indeed.fr

9. https://www.jobijoba.com

10. https://www.jobs.bg/

11. https://www.jobs.cz/

12. https://www.linkedin.com/

13. https://www.profesia.sk/

14. https://www.profession.hu/

15. https://www.reed.co.uk/ 